\title{
NATIONAL LAW DEVELOPMENT AS IMPLEMENTATION OF PANCASILA LAW IDEALS AND SOCIAL CHANGE DEMANDS ${ }^{\Omega}$
}

\author{
Achmad Irwan Hamzani dan Mukhidin \\ Faculty of Law Universitas Pancasakti, Indonesia \\ E-mail: hamzaniachmad@gmail.com
}

\begin{abstract}
Social life changes over time. The response to social change and law change is all important. The ideal national law system Indonesian people expect is Pancasila law system. The problem in this research is First, what is the description of the Pancasila law ideals? Second, why development of national law as implementation of Pancasila law ideals is important? and Third, is national law development also the social change demands? This research employs normative approach which constitutes secondary data in the form of library materials. The analysis applied induction-interpretationconceptualization. The results show that Pancasila law ideals is an expectation of a law system rooted in Pancasila which is a way of life of the Indonesian nation. The development of national law system is an attempt to establish its own product laws. The importance of national law development is to manifest the Pancasila law ideals. The law development in the context of social change is to meet social change. The national law development will be more effective if initiated from the substance of law.
\end{abstract}

Keywords: development, national law, ideals of law, Pancasila, social change.

\begin{abstract}
Abstrak
Kehidupan sosial akan terus berubah. Respon terhadap perubahan sosial dengan perubahan hukum sangat penting. Sistem hukum nasional yang dicita-citakan oleh bangsa Indonesia adalah sistem hukum Pancasila. Permasalahan dalam penelitian ini adalah pertama, bagaimanakah deskripsi cita hukum Pancasila; kedua, mengapa pembangunan hukum nasional penting sebagai implementasi cita hukum Pancasila dan ketiga, apakah pembangunan hukum nasional juga sebagai tuntutan perubahan sosial? Penelitian ini menggunakan pendekatan normatif. Data penelitian yang digunakan adalah data sekunder berupa bahan pustaka. Analisis yang digunakan induksi-intepretasi-konseptualisasi. Hasil penelitian ini menunjukan bahwa cita hukum Pancasila merupakan harapan adanya sistem hukum yang berakar pada Pancasila sebagai pandangan hidup bangsa Indonesia. Pembangunan sistem hukum nasional merupakan upaya untuk membentuk hukum produk sendiri. Pentingnya pembangunan hukum nasional agar terwujud cita hukum Pancasila. Pembangunan hukum dalam konteks perubahan sosial adalah sebagai pemenuhan prubahan sosial. Pembangunan hukum nasional akan lebih efektif apabila dimulai dari substansi hukum.
\end{abstract}

Kata kunci: pembangunan, hukum nasional, cita hukum, Pancasila, perubahan sosial

\section{Introduction}

Social life consistently changes and develops. Wherever it is, society will be gradually affected by the social change. There are two kinds of social change; material change and immaterial change. Material change is the change of structure, institution, organization, authority, and social interaction while immaterial change is the change of value, idea, ideology, and the way of life perspective which is able to influence the material change. The theory ex- plaining about the social change has been often formulated by sociologists. ${ }^{1}$ Social change is

$\Omega$ This paper is part of the research besed on competency that funded by Directorate Research and Community Service of Ministries of Research, Technology and Higher Education of The Republik of Indonesia on 2017, with contract number: 121.e/K/F/LPPM/UPS/V/2017.

Juliana Lumitang, "Pengaruh Perubahan Sosial terhadap Kemajuan Pembangunan Masyarakat di Desa Tara-tara I", Jurnal Acta Diurna" Vol. IV No. 2, December2015, p. 78. 
when the difference of social aspects over time by systematized social process. ${ }^{2}$

Basically, social change is natural for humans with unlimited necessity and keeps developing. ${ }^{3}$ Practically, it will significantly influence law which is now commonly written. If the social change unfit the law, then there will be a conflict by which law cannot reach and solve, whereas the society require the law. Law does not only limit and impose the punishment but also to give a chance and to encourage the society to always be dynamic. ${ }^{4}$

If the prevailing law cannot reach the social change, it will be social lag, where the law is not able to give and serve the social necessity. For instance, the conflict in Indonesia hardly to solve are electricity stealing, terrorism of Bali Bomb I, sexual harassment, and others. At that time the existing law could not reach and solve those cases causing the law vacuum. Ideally the law is futuristic to anticipate the change of society.

Law also functions as facilitation of human interaction to reach social order. Idea of the law is made to gain three purposes; justice (gerechmatigheid), benefit (doelmatigheid), and law certainty (rechtmatigheid) in social living. Rule of law has a philosophical validation as the idea of law that reflects on justice value in society. ${ }^{5}$ Other function of law is as the ethical control. Law is equal to central organ. The control is in certain organ given the capacity. An equal control is also mechanic-automatic, where it guides the behaviour. ${ }^{6}$ Both functions have put the law as a tool of social control in society.

2 Hadriana Marhaeni Munthe, "Modernisasi dan Perubahan Sosial Masyarakat dalam Pembangunan Pertanian; Suatu Tinjauan Sosiologis", Jurnal Harmoni Sosial, Vol. II No. 1, September 2007, p. 4.

3 Baharuddin, "Bentuk-bentuk Perubahan Sosial dan Kebudayaan”, Jurnal Alhikmah, Vol 9 No. 2, December 2015, p. 181.

4 Zulfi Diane Zaini, "Perspektif Hukum sebagai Landasan Pembangunan Ekonomi di Indonesia; Sebuah Pendekatan Filsafat", Jurnal Hukum, Vol. XXVIII No. 2, December 2012, p. 930-931.

5 I Nyoman Nurjaya, "Memahami Kedudukan dan Kapasitas Hukum Adat dalam Politik Pembangunan Hukum Nasional", dalam Jurnal Perspektif, Vol. XVI No. 4, September 2011, p. 240-241.

6 Netty Endrawati, "Sistem Hukum dan Pembangunan Hukum", Jurnal Wastu, Special Volume, December 2007, p. 43.
The latest independent countries and the developing countries urgently require the change of law. Psychologically, the independent countries have a will to quickly remove the colonial track in their countries. It is common when an independent country will replace the legacy of law system from colonials with the suitable one as the society has. ${ }^{7}$

Based on law perspective, the independence of Indonesia is only an authority shift from the colonial to the indigenous one. The law sys-tem of colonial remains existed and be valid as the change has not happened. Until now, Indonesia does not have its own national law. National law is just an idea. It means change of law are just the replacement colonial era to its own product, changing or completing outdated law. The preferred national law system is Pancasila law system. In this regards, the researcher finds it important to study about the development on national law as a fulfillment of Pancasila law ideals and the social change demands.

From the explanation above, the problems are formulated as follows: first, what is the description of the Pancasila law ideals? Second, why national law development as implementation of Pancasila law ideals is important? and third, whether national law development is the demands of social change?

\section{Research Method}

This research belongs to normative law research since it studies theoretical aspect of written law. The approach is also normative using law theory and secondary data in form of written documents obtained through library study. Then induction, interpretation, conceptualization are applied using interactive model including data reduction, data presentation and conclusion.

\section{Discussion \\ Pancasila Law Ideals}

Oksep Adhayanto, "Perkembangan Sistem Hukum Nasional”, Jurnal Ilmu Hukum, Vol. IV No. 2, July 2014, p. 208. 
Pancasila in Indonesia law order is positioned as source of all of law sources. This relates to Preamble of the 1945 Constitution of Republic of Indonesia (UUD NRI 1945) which places Pancasila as national principle. Pancasila is also way of life of Indonesian people formulated in five-point ideology. Each ideology contains fundamental value and becomes operational five pillars in practical law development. The unity of five-point ideology creates value system that can be elaborated in law system. $\mathrm{Na}$ tional law becomes the idea of nation that is rooted from Pancasila as way of life.

Pancasila law ideals is a law that develops along with interests, social value and concept of justice to one prismatic law by taking the good elements. Pancasila contains good elements and fits to culture values of Indonesia that is called as prismatic concept.

There are four elements of Pancasila: first, Pancasila includes the elements both of individualism and collectivism point of view; second, Pancasila integrates the legal state concept "Rechtsstaat, which emphasizes the civil law and legal certainty, and "The Rule of Law" which emphasizes on the common law and sense of justice; third, Pancasila accepts law as tool of social engineering and the sense of justice in the society (living law); fourth, Pancasila follows the concept of religious nation state, which is neither a state of a religion nor a state with no religion. ${ }^{8}$

Pancasila law ideals represent the nation's ideals mentioned in the Preamble of the 1945 Constitution. It is a legal system which is oriented to the values of divinity (religious), humanities, and society (nationality, democracy, and social justice).

The Pancasila Law System is a system based on the characteristic of the nation's culture. The law must be in line with each nation's basic culture character. Since the law serves the society, so its system must be as characteristic as the culture of the society. So, the

8 Moh. Mahfud MD, "Politik Hukum dalam Perda Berbasis Syari'ah“, Jurnal Hukum, Vol. XIV No. 1, January 2017, p. 11. law system of Pancasila is the characteristic law system for Indonesian society.

\section{Urgency of National Law Development as Pan- casila Law Ideals Implementation}

The law development is an effort to renew the previous and irrelevant ones. The renewal means to replace the old law with the new one. In this case, the law development has the same interpretation as the law renewal. Meanwhile, the national law is based on the constitution and Pancasila as the national principle 9 or the law created by the ideals sense and engineering of Indonesia nations.

The law development includes legislation and functioning the living law. The legislation is the formulation of regulation and positive law. Meanwhile, the law functioning is implemented in the obedience to customs and jurisprudence. Above all, the legal politic in Indonesia tends to simplify the law development on its legal material planning list that will be create in National Legislation Program (Prolegnas). ${ }^{10}$ The government of Indonesia has been tried for a long time to create the National Law through the legislation. They tended to replace the out to date regulation and create the new regulation which is partial in certain field.

Having their own law can show the Indonesia nations' identity which is in line with the independence ideals. It has been implemented through National Law Development program. The absence of the national law system product is a legal problem in Indonesia since the beginning era of the Indonesia independence until today.

The law development effort in Indonesia must obey the national principle and purpose which are mentioned in the 1945 Constitution of Republic of Indonesia:

"...protect the whole people of Indonesia and the entire homeland of Indonesia, and in order to advance general prosperity, to develop the nation's intellectual life, and to contribute to the implement-

M. Sularno, "Syari'at Islam dan Upaya Pembentukan Hukum Positif di Indonesia", Jurnal al-Mawarid, Vol. XVI No. 2, December 2006, p. 216.

10 Moh. Mahfud MD., op.cit., p. 3-4. 
ation of a world order based on freedom, lasting peace and social justice". ${ }^{11}$

The duty to enhance the general prosperity must have the implementation in the legal product developed.

As the implementation, the national law must serves the national interests and way to achieve nation prosperity, justice and the society order ${ }^{12}$. The law as the values implementation must includes the values highly obeyed by the Indonesian society. The concept followed is the development law concept. It is to set the law as a tool to develop people with legal functions emphasized as: the security and order keeper, development tool, and people education tool. ${ }^{13}$

The national law development is aimed to create the national law system which serves the national interest and its materials based on the Indonesia nation's point of view and belief. In addition, it must also serves the new problem that requires the legal need's response to support the government's general duty and to improve the national interests. The long-term development of national law development has been launched, that is to replace the Netherland colonials law product by the statutory law.

After the reform era, the law development had big reform as the reform demands on various development fields. Cited in Attachment of Law Number 17 Year 2007 of The 2005-2025 National Long-Term Development Planning, the effort to realize the national law system persists including:

"legal substances development. Both written and unwritten law have a mechanism to form the better national law according to the development of necessity and the people aspiration...".

11 Erfandi, "Implementasi Nilai-nilai Pancasila dalam Pembangunan Sistem Hukum Pidana di Indonesia", Jurnal Ilmiah Pendidikan Pancasila dan Kewarganegaraan, Vol. I No. 1, June 2016, p. 23-24.

12 Frankiano B. Randang, "Membangun Hukum Nasional yang Demokratis dan Cerdas Hukum", Jurnal Servanda; Jurnal Ilmiah Hukum, Vol. III No. 1, January 2009, p. 2.

13 Wicipto Setiadi, "Pembangunan Hukum dalam Rangka Peningkatan Supremasi Hukum", Jurnal Rechtsvinding, Vol. I No. 1, April 2012, p. 6.
The important basic problem in developing the national law system is how to create a conducive law system for the various sub systems, various substances, and the development of law fields needed by the society. In addition, it must be favorable to create society's law awareness, legal freedom, and freedom to enforce the rights and obligations according to the valid regulations. ${ }^{14}$

Indonesia, according to founding fathers, is considered as a state of law. However, the blueprint and macro design that explain thoroughly the idea of a state of law is not yet supported by comprehensive formula, and only assisted by partial law sector. It is inconsistent with the civil law tradition that inclined to the law making and submit to paradigm and fictional doctrine which judge that once a norm of law is settled, at that moment, everyone knows law.

It is urgent for the national law development to materialize Pancasila. If the direction of the national law system started from law making, it then shall change every form of law of Dutch's product such as, the book of criminal law, the book of civil law, the book of trade law, completing and changing regulations product that is not in line with era development. The material comes from the view and belief of Indonesia aside of the consideration of the global development. The establishment of national law also need to respect unwritten law, such as customary law and Islamic law that has become the living law.

\section{Establishment of National Law as Social Cha- nge Demands}

Discussion on law and citizens structure is beneficial to explain why law develops. Citizens structure can be an obstacle in terms of facility in social institution that potentially enables law to have its form. Law is seen as a institution that is not autonomous. Just like what Eugen Ehrlich said that:

"..even now and in the upcoming era, the centre of activity and the growth of law is not in law regulation, law science, also

14 Frankiano B. Randang, op.cit., p. 4. 
not in court decision, but in the citizens itself". ${ }^{15}$

Citizens as the center of law establishment is the hope of newborn of law regulation. Every social changes taking place in the society is an instrument that can give affect to the center of activity and establishment of law. Law keeps developing over time along with the rising problem in society. The concept of the rule of law currently dominating comes from the process of history. Law relates to social changes in many ways, and even as reflection of the fulfillment of social needs.

Pameo ubi societas ibi ius is meant for wherever there is society, there is law that it reflects the connection of social change and the change of law. Society exists and creates law, society changes, and so does law. Based on its development, the change of law is processed through two forms; the society takes the lead of being changed, and the law that settles the changes (passive changes), or the law as a tool of social engineering.

There are two opposites perspectives about the law functionality. First, The perspective that law is supposed to follow social changes. This perspective is suggested by Carl von Savigny; that law is found not created. Second, The perspective that law is a tool for the renewal of society suggested by Roscoe Pond. It is unnecessary to debate over law adjustment to social change and how law becomes the booster to social change since in any place of the change of law activity, law has put so much role in that change. Law functions as a protection of human matter. The change of law that occur is a logical consequence from a dynamic law. ${ }^{16}$

The history of the development of law theory is also influenced by the theory of social changes, just like in doctrine of history, sociological jurisprudence, and realism. The doctrine of history is filled with popular figure like, Carl von Savigny, that considers law as a nation soul growth (volkgeist). The doctrine provides ac-

15 Peter Curzon, 1998, Juriprudence Lecture Notes, Britania: Cavendish-Routledge Publishing, p. 169.

16 Achmad Ali, 2002, Menguak Tabir Hukum, Jakarta: Toko Gunung Agung, p. 278. knowledgement on how important the legitimacy to unwritten law or living law. Roscoe Pound also legitimized the law interdependence based on non-law elements. According to pound, state, social,and personal matter can cause a law to be not dogmatic. Moreover, realism is also affected by various of social change mode. Benjamin Ntan Cardozo, one of the realists states that "every decision born from the judges is not just for interpretation of law, but imagine it like recipe". Judges decision is a recipe coming from either law or non-law elements such as politics, histories, economics, ideologies, social pressure, and cultures. This is in line with Ronal Dworkin's critics that law positivism is yet completed to accommodate every matters and rights of people with laws. ${ }^{17}$

The theory of social changes is unsurprised theory. Just like what a theory is, it is born from a process of history that relates to the space and time. Social theory is dynamics in accordance with the development of human race. The newborn of the social theories itself is a research result done by the west. ${ }^{18}$

Max Webber divides social change model into three steps including traditional society, charismatic society, and rational society. The further development of social change theory is relatively similar to the classification by Max Weber which is labeled as social solidarity. Then, Emil Durkheim divides two patterns of social changes into mechanic solidarity and organic solidarity. The social change theory is also developed by Talcolt Parson. Parson argued that traditional society as Max Weber considered or still in the limit of mechanic solidarity is formed as united society. Then, the next generated Marxism to Frankfurt that renews the critical perspective of Karl Max. ${ }^{19}$

The occurring social change has its own phase. Law is influenced by each type of social change phases. The law that once released itself from social, politics, economics, ideologies, and morals elements becomes inevitable. The

\footnotetext{
17 Ibid., p. 283.

18 Soerjono Soekanto, 2008, Pokok-Pokok Sosiologi Hukum, Jakarta: Rajawali Press, p. 212.

19 Ibid., p. 214.
} 
law experts eventually use some social changes model for the law growth in practical region of law making and courts decision.

Every nation has its own unique characteristics which is shaped along with the history and culture development of its society. Every nation has its own characteristics and quality which intrinsically means no superior or inferior nation. The same thing happens with the law formation that closely linked to society culture. ${ }^{20}$

Indonesia uses modern law system. Nevertheless, this system is not developed from Indonesian people but from Dutch colonials. Institution law structure such as value, justice, role, and organization are not from local genius. In fact, the modern law with its elements applied in Indonesia is the same as institutions that grow and develop in Europe. It is undeniable that before modern law developed in XIX and XX century, law developed in Europe for ten centuries. Law in Europe does not appear out of the blue, for thousand years in Europe law developed along with its society development. ${ }^{21}$ As constitutional law, Indonesia must be dynamic in controlling society needs to be harmonious and at least there is a conflict settlement mechanism. The law must be clear, assertive, and regulate people interest. Law material must contain justice to realize prosperity. ${ }^{22}$

A product of ideal national law development must be a law that reflects Indonesian people characteristics which contain in Pancasila. Indonesia characteristics are religious, uphold social and family norms, discussion, mutual cooperation, tolerance etc. Indonesia's spirit must be shown in national law product. It is wrong to ignore the spirit by using import concepts. Therefore, it will detains law national development. ${ }^{23}$

20 Yanis Maladi, “Eksistensi Hukum Adat dalam Konstitusi Negara Pasca Amandemen", Jurnal Mimbar Hukum, Vol. 22 No. 3, October 2010, p. 452.

21 Suteki, 2013, Desain Hukum dalam Ruang Sosial, Yogyakarta: Thapa Media, 2013, p. 59-60.

22 Yohanes Suhardin, "Peranan Hukum dalam Mewujudkan Kesejahteraan Masyarakat", Jurnal Hukum Pro Justitia, Vol. XXV No. 3, July edition 2007, p. 271.

23 Adhayanto, op.cit., p. 219.
In process of law formation, full participation of social groups or individual in society play a significant role. This is a consequence of democratic mechanism in Indonesia as politics system that opens for public participation to determine the policy. Law product must be responsive instead of showing government interest. ${ }^{24}$

National law development system cannot be separated from the change of social life order. The law product must reflect the social life of its nation. Law sub systems in Indonesia should not against the values in Indonesian people. The influence from other law systems such as Anglo Saxon, continental Europe, Islamic law, and traditional law must be considered as a comparison. National law system must balance das sein and das sollen ${ }^{25}$ that often biased.

The dimension of national law system is wide and can be categorized into three elements, which are law substance, law structure, and law culture. The researcher believes that from those elements, the development of law will be more effective if it started by law substance or material. After law substance is established, structure and culture of law will follow. In fact, law is politics product, so politics also will determine the law. Law politics can be free variable, but law becomes dependent variable. The position of politics determinant will emerge the law style. ${ }^{26}$ The direction of law politics in Indonesia within law development is take in to simplify the legislation of law material.

In order to make national law development fulfill the social development need, society material and spiritual needs also must be fulfilled. The law that formulated is not just a bunch of Article. The effectiveness of law is not a separate problem, but it related to social problems. National law development will relate to local, regional, and global developments.

24 Peni Jati Setyowati, "Fungsi Filsafat, Agama, Ideologi dan Hukum dalam Perkembangan Politik di Indonesia", Jurnal Yuridika, Vol 31 No. 1, January-April 2016, p. 38.

25 Adhayanto, op.cit., p. 221-222.

26 Laili Bariroh, "Politik Hukum Nasional dan Hegemoni Globalisasi Ekonomi”, in Jurnal Review Politik, Vol. II No. 2, December 2012, p. 200. 


\section{Conclusion}

Based on the explanation above, it can be concluded several things. first, Pancasila law ideals is an expectation of a law system based on Pancasila as Indonesia's nation way of life. Pancasila law ideals portrays nation's outlook which contained in the preamble of Indonesian Constitution 1945. A law system that oriented to religious, humanity, and society values. Second, the national law development system is an effort to form our own law product. National law development is important to realize Pancasila law ideals. To materialize it, the development of national law must capable to change all of the Dutch regulation products, and develop more on our own regulation products that are not suitable with current development. Third, Law development in context social changing, law is a reflection of social needs fulfillment. Social change in society is an instrument that can affect law development. Development of law including law substance, law structure, and law culture. The development of law will be more effective if it started by law substance and then law structure and culture will follow. The direction of law politics in Indonesia also simplifies the legislation of law material.

\section{Suggestion}

Based on the discussion on national law development as pancasila law ideals implementation and the demands of social change, the researcher provides suggestions as follows. First, government and people's Representative Council (DPR) have to realize national law system to replace the colonial Dutch law system as soon as possible. The development of national law is very important to realize pancasila law ideals. Second, Law scholars conduct perpetual study on the significance of national law development in the future. National law profile must be studied thoroughly to produce law appropriate with Indonesia society value and up to date to current development.

\section{References}

Adhayanto, Oksep. "Perkembangan Sistem Hukum Nasional”. Jurnal Ilmu Hukum. Vol. IV No. 2. Juli 2014. Pp. 207-228;

Ali, Achmad. 2002. Menguak Tabir Hukum, Jakarta: Toko Gunung Agung;

Baharuddin. "Bentuk-bentuk Perubahan Sosial dan Kebudayaan". Jurnal Alhikmah, Vol. 9 No. 2. Desember 2015. Pp. 180-205;

Bariroh, Laili. "Politik Hukum Nasional dan Hegemoni Globalisasi Ekonomi". Jurnal Review Politik. Vol. II No. 2. December 2012. Pp. 196-218;

Curzon, Peter. 1998. Juriprudence Lecture Notes, Britania: Cavendish-Routledge Publishing;

Endrawati, Netty. "Sistem Hukum dan Pembangunan Hukum". Jurnal Wastu. Special Volume. December. 2007. Pp. 41-57;

Erfandi. "Implementasi Nilai-nilai Pancasila dalam Pembangunan Sistem Hukum Pidana di Indonesia". Jurnal Ilmiah Pendidikan Pancasila dan Kewarganegaraan, Vol. I. No. 1. June 2016. Pp. 23-32. DOI: 10.179 77/jippk.v1i1.344;

Lumitang, Juliana. "Pengaruh Perubahan Sosial terhadap Kemajuan Pembangunan Masyarakat di Desa Tara-tara I". Jurnal Acta Diurna". Vol. IV. No. 2. December 2015. Pp. 1-9;

Mahfud MD, Moh. "Politik Hukum dalam Perda Berbasis Syari'ah". Jurnal Hukum, Vol. XIV No. 1. January 2017. Pp. 1-21;

Maladi, Yanis. "Eksistensi Hukum Adat dalam Konstitusi Negara Pasca Amandemen". Jurnal Mimbar Hukum. Vol. 22 No. 3. October 2010. Pp. 450-464. DOI: 10.22146/ jmh.16235;

Munthe, Hadriana Marhaeni. "Modernisasi dan Perubahan Sosial Masyarakat dalam Pembangunan Pertanian; Suatu Tinjauan Sosiologis". Jurnal Harmoni Sosial. Vol. II No. 1. September 2007. Pp. 1-7;

Nurjaya, I Nyoman. "Memahami Kedudukan dan Kapasitas Hukum Adat dalam Politik Pembangunan Hukum Nasional". Jurnal Perspektif, Vol. XVI No. 4. September 2011. Pp. 236-243;

Randang, Frankiano B. "Membangun Hukum Nasional yang Demokratis dan Cerdas Hukum". Jurnal Servanda; Jurnal Ilmiah Hukum, Vol. III No. 1. January 2009. Pp. 3747; 
Setiadi, Wicipto. "Pembangunan Hukum dalam Rangka Peningkatan Supremasi Hukum". Jurnal Rechtsvinding, Vol. I No. 1. April 2012. Pp. 1-15;

Setyowati, Peni Jati. “Fungsi Filsafat, Agama, Ideologi dan Hukum dalam Perkembangan Politik di Indonesia". Jurnal Yuridika, Vol. 31 No. 1. January-April. 2016. Pp. 37-53;

Soekanto, Soerjono. 2008. Pokok-Pokok Sosiologi Hukum, Jakarta: Rajawali Press;

Suhardin, Yohanes. "Peranan Hukum dalam Mewujudkan Kesejahteraan Masyarakat".
Jurnal Hukum Pro Justitia, Vol. XXV No. 3. July 2007. Pp. 270-282;

Sularno, M. "Syari'at Islam dan Upaya Pembentukan Hukum Positif di Indonesia". Jurnal al-Mawarid, Vol. XVI No. 2. December 2006. Pp. 211-219;

Suteki. 2013. Desain Hukum dalam Ruang Sosial, Yogyakarta: Thapa Media;

Zaini, Zulfi Diane. "Perspektif Hukum sebagai Landasan Pembangunan Ekonomi di Indonesia; Sebuah Pendekatan Filsafat". Jurnal Hukum, Vol. XXVIII No. 2. December 2012. Pp. 929-957. 